Biol Neonate 1992;62:I-IV

\title{
Contents, Vol. 62, No. 4, 1992
}

Evans, D.H. Doppler Ultrasound and the Neonatal Cerebral

271

Circulation: Methodology and Pitfalls

191

Maulik, D.; Arbeille, P.; Hemodynamic Foundation of Umbilical Arterial

Kadado, T. Doppler Waveform Analysis

Wyatt, J.S. Near Infrared Spectroscopy-Investigation and 290

Assessment of Perinatal Brain Injury

Abstracts

Tours, October 7-10,1992 International Symposium on Fetal and Neonatal

Neurology

Follow-Up 305

Author Index 308

192

International Symposium on Fetal and Neonatal Neurology International Symposium on Fetal and Neonatal Neurology

Tours,

October 7-10, 1992

Editor

Elie Saliba, Tours

\section{KARGEIl}

19 figures and 23 tables, 1992

International Symposium on Fetal and Neonatal Neurology

Sponsored by

S. Karger AG, Basel, Switzerland

The extended contents of this issue was made possible with support of Prof. J.P. Relier, Paris

and the Heinz Karger Memorial Foundation, Basel

S. Karger

Medical and Scientific Publishers Basel $₫$ Freiburg · Paris · London New York · New Delhi · Bangkok Singapore $\cdot$ Tokyo $\cdot$ Sydney

Drug Dosage

The authors and the publisher have exerted every effort to ensure that drug selection and dosage set forth in this text are in accord with current recommendations and practice at the time of publication. However, in view of ongoing research, changes in government regulations, and the constant flow of information relating to drug therapy and drug reactions, the reader is urged to check the package insert for each drug for any change in indications and dosage and for added 
warnings and precautions. This is particularly important when the recommended agent is a new and/or infrequently employed drug.

All rights reserved.

No part of this publication may be translated into other languages, reproduced or utilized in any form or by any means, electronic or mechanical, including photocopying, recording, microcopying, or by any information storage and retrieval system, without permission in writing from the publisher or, in the case of photocopying, direct payment of a specified fee to the Copyright Clearance Center (see 'Information for Readers and Subscribers').

(C) Copyright 1992 by S. Karger AG, P.O. Box, CH-4009 Basel (Switzerland) Printed in Switzerland on acid-free paper by Thür AG Offsetdruck, Pratteln ISBN 3-8055-5700-0 $19 \ddot{U}$ 